\title{
Self Reported Hearing Impairments And Associated Risk Factors Among Metal And WoodWork Workers in Gondar Town, North West Ethiopia, 2020.
}

Eshetu Abera ( $\square$ eshetuabera2021@gmail.com )

Gondar College of Medical Sciences: University of Gondar

WalelegnWorku Yallew

University of Gondar College of Medicine and Health Sciences

Sintayehu Daba Wami

University of Gondar College of Medicine and Health Sciences

\section{Research}

Keywords: Hearing impairment, the noise exposure, Prevalence, Risk factor

Posted Date: April 7th, 2021

DOl: https://doi.org/10.21203/rs.3.rs-390058/v1

License: () (1) This work is licensed under a Creative Commons Attribution 4.0 International License. Read Full License 


\section{Abstract \\ Background}

Globally, the prevalence of occupational noise-induced hearing loss ranges from 16-24\%. Moreover, occupational noise exposure is a major public health problem among metal and woodwork workers in sub-Saharan Africa including Ethiopia. However, there is limited evidence about the risk of hearing impairments and level of noise exposure in Ethiopia.

\section{Methods}

In this cross-sectional study 580 metal and woodwork employees in Gondar town were surveyed from February10-March 25/2020. The data were collected through an interviewer-administered questioner and the noise exposure level was measured using an ICE 651 type II sound pressure level meter. The data were entered into EPI info version7 and analyzed using SPSS20 version software. Bivariable and multivariable logistic regression analyses were performed to identify factors associated with hearing impairments.

\section{Result}

The overall prevalence of self-reported hearing impairment was $20.7 \%$ [95\% Cl: (17.4-24)]. From the total participants, $11.2 \%$ of the woodwork and $9.5 \%$ of metal workers reported hearing impairments. The mean $( \pm \mathrm{SD})$ noise exposure level in both industries was $96.63 \pm 3.7 \mathrm{dBA}$. Listening to music using earphones for more than two hours per day $[\mathrm{AOR}=5.33,95 \% \mathrm{Cl}(1.29,21.9)]$ and playing music with loud volume $(A O R=3.75(1.13,12.43)$ were significant risk factors for hearing impairments.

\section{Conclusion}

The prevalence of hearing impairment is comparable in metal and woodwork worker, but higher noise exposure level is recorded in woodwork industry and the majority of the employees exposed to the noise level above the permissible exposure limit. Therefore, the hearing conservation program shall be implemented in both wood and metalwork industries.

\section{Introduction}

There is a great global concern about industrial noise exposure in metal and woodwork industries (1). Occupational noise exposure has been documented since at least the 18th century when it was noted that copper miners developed hearing loss as a result of noise from hammering on metals $(2,3)$. Noise is defined as an unwanted and unpleasant sound, which interferes with human communication, comfort, and feeling of wellbeing (4-6). Hearing loss caused by work-related noise exposure is referred to as occupational noise-induced hearing loss $(\mathrm{NIHL})(1,6,7)$ and it is estimated worldwide 16 to $24 \%$ (7)and is 
the second-most common self-reported occupational injury or illness, accounting for $7 \%$ of the total hearing loss in developed countries and $21 \%$ in developing countries (8). Hearing impairment is the most common sensory deficit. Over 180 million people develop a disabling hearing impairment $(\mathrm{HI})$ during adulthood with occupational noise-induced hearing loss ( $\mathrm{NIHL}$ ) estimated to account for $16 \%$ of this case (9) and it is a major challenge for public health organizations (10). It is estimated that approximately 600 million workers are exposed to occupational noise (11).

A Study in the USA showed that the weighted prevalence of workplace noise exposure was highest for mining $(76 \%$, SE $1 / 47.0)$ followed by lumber/wood product manufacturing (55\%, SE $1 / 42.5)$ (7). In Nepal metalworkers, the prevalence of $\mathrm{NIHL}$ is $30.4 \%$ and $4.1 \%$ in controls with a significant odds ratio of 10.3 (6). In Greek wood industries average noise level is beyond the acceptable limit values (12) and in southeast Asia wooden furniture industry noise-induced permanent threshold shifts were reported in $34.7 \%$ of the participants and noise levels up to $130 \mathrm{dBA}(9)$. A study conducted in Saudi Arabia showed that all mean noise levels in all studied metalwork factories and $50 \%$ of studied woodwork industries were higher than the standard level of $85 \mathrm{dBA}(1)$.

Literature indicated that factors influencing the occurrence of noise-induced hearing loss in the metal and woodwork industry include noise intensity and duration of exposure $(9,13)$, gender, age $(6)$, non-use of hearing protection, cigarette smoking, head injury, and alcohol consumption $(6,14,15)$. Extraneous noise sources like market, noise from traffic flow, previous occupation like the garage, construction, military, training were also identified as risk factors $(16,17)$. Occupational noise exposure and related hearing impairment are a public health problem in sub-Saharan Africa due to rapid ongoing industrialization (6) and it represents a much heavier burden in the region due to lack of noise prevention programs and awareness (18).

Nowadays the number of metal and wood manufacturing factories is increased in Ethiopia to meet the rising demand for different infrastructure. The effect of noise generated in the metal and woodwork industries in Ethiopia and hearing impairment of the workers in this sector has not been investigated and the level of noise exposure is not known. Furthermore, the working condition in this industry has received little attention and appropriate noise control measures are not implemented.

Therefore, the purpose of this study is to determine noise exposure level, the prevalence of self-reported hearing impairments, and associated risk factors among metal and wood manufacturing workers in Gondar town.

\section{Material And Methods}

\section{Study design and settings}

An institutional-based cross-sectional study was conducted from February 10- March 25/2020. The study was conducted in 46 metals and 45 woodwork industries in Gondar town, Ethiopia. Gondar town is the capital city of the central Gondar zone in Amhara regional state and it is one of the historical towns in the 
country and located $750 \mathrm{~km}$ from northwest of Addis Ababa. The metal and woodwork industry is one of the known industries that generate high noise levels that can affect the hearing condition of the workers unless a hearing conservation program is implemented.

\section{Source and study populations}

All metal and woodwork workers in Gondar town were the source population and Workers who have worked at least for six months and above in the metal and woodwork industry were included in the study (19).

\section{Sample size and sampling procedure}

For the first objective sample size was done by using a single proportion formula by considering $95 \%$ confidence interval, $30.4 \%$ prevalence of noise-induced hearing loss among metalwork worker(6), and $4 \%$ margin of error and by adding $10 \%$ non-response rate, the final sample size for the first objective was 599 , and sample size for the second objective was 644, which is determined by open EPI info version 7 considering $95 \% \mathrm{Cl}$, and power $80 \%$ and factors that have strong significant relation with hearing impairment $(11,20)$. The sample size for the second objective is higher than the sample size for the first objective and the final sample size for this study was 644, which is near to all target population (729) in the town and a survey sampling technique was used to select the study participants among wood and metalwork workers.

\section{Data collection tool and procedure}

The data was collected through an interviewer-administered data collection technique by using a pretested structured questioner that prepared from different kinds of literature and the questioner is closeended with multiple choice and rating scale and includes socio-demographic, working condition, behavioral characteristics of the study participant, previous occupational noise exposure, occupational noise exposure level with duration and intensity of exposure and sign and symptoms of noise-induced hearing impairment. First, the questioner was prepared in English and translated to the local language (Amharic), and checked for consistency. Workplace noise exposure level was measured by a sound level meter (according to IEC 651, type II), and average SPL measurement taken over 15 minutes in the oneminute interval at workers head level(1) during the work is performed and Average noise level (Ave) was calculated using the following logarithmic formula.

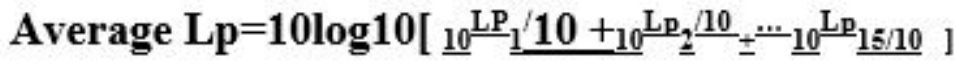

15

\section{Operational definitions}

Hearing impairment was defined as a study participant who experience the difficulty of hearing when people speak, communication difficulty (misunderstanding what is heard), tinnitus (ringing or buzzing in their ears in the absence of external noise source) was considered as he/she have hearing impairments 
$(13,21)$ and coded as 1 for had experience hearing impairments and 0 for not had experience hearing impairments.

\section{Ear infection}

In this study ear infection was ascertained by the question do you have a history of ear infection under /above the age of 18 years and in this regard Certain viral infections in the inner ear destroying the cochlea, producing total deafness(19).

Smoking: In this study smoking was ascertained based on the questions: 'have you ever smoked?' and 'are you a current smoker?' Smoking will also categorize as non-smokers (never-smokers or less than 6 months or less than 20 packs of cigarettes or $12 \mathrm{oz}$. of tobacco in a lifetime, or less than one cigarette a day for one year)) and ever-smokers (current or past smokers)(11).

\section{Data management and Analysis}

The data were entered using EPI info version7 software and exported to SPSS version 20 software for further analysis. A chi-square test was done to see the association between different factors and the magnitude of hearing impairments. Bivariable and a multivariable regression model were used to identify the association between hearing impairment and independent variables. The model fit test $(p=0.655)$ and the reliability test (0.7) were assessed. P-value of less than 0.05 and odds ratio with $95 \% \mathrm{Cl}$ was used to declare the presence and the strength of association respectively.

\section{Data quality control}

The quality of data was assured through careful design, translation, and retranslation of the questionnaire as well as pre-testing on $5 \%$ of the sample from another site of metalwork and woodwork industry, and this was enabled to assess the quality of questioners that need correction and correct it accordingly. The training was also given to the data collectors and supervisors before the pretest. The supervisors and principal investigator closely followed the day-to-day data collection process and ensure completeness and consistency of the collected questionnaire. Proper categorization and coding of the data were made and double data entry was performed.

\section{Ethical consideration}

The ethical issue was assured by an Institutional Review Committee of the University of Gondar and participants were also informed and confidentiality assured by using an anonymous questionnaire.

\section{Result}

\section{Socio-demographic characteristics of study participants}

From a total of 626 wood and metalwork workers, 580 respondents with a response rate of $92.7 \%$ were fully participated and considered for the analysis. The majority (93.6\%) of the study participants were 
males and the mean age of respondents was $26.32( \pm 7.32)$ years of age. Half $(50.9 \%)$ of the participants had work experience below 3 years and $5.5 \%$ had above 13 years of work experience (Table 1 ). 
Table 1

Socio-demographic characteristics of wood and metalwork industry workers in Gondar town, 2020 (n $=580)$

\begin{tabular}{|c|c|c|c|}
\hline Variables & Category & Frequency & Percent \\
\hline \multirow[t]{2}{*}{ Sex } & Male & 543 & 93.6 \\
\hline & Female & 37 & 6.4 \\
\hline \multirow[t]{4}{*}{ Age } & $15-24$ & 265 & 46.2 \\
\hline & $25-34$ & 234 & 40.3 \\
\hline & $35-44$ & 59 & 10.2 \\
\hline & $>44$ & 22 & 3.8 \\
\hline \multirow[t]{4}{*}{ Religion } & Orthodox & 476 & 82.1 \\
\hline & Muslim & 96 & 16.2 \\
\hline & Protestant & 6 & 1 \\
\hline & Others & 2 & 0.3 \\
\hline \multirow[t]{2}{*}{ Marital status } & Single & 432 & 74.5 \\
\hline & Married & 148 & 25.5 \\
\hline \multirow[t]{4}{*}{ Family size } & $<2$ & 199 & 34.3 \\
\hline & $2-3$ & 265 & 45.7 \\
\hline & $4-5$ & 97 & 16.7 \\
\hline & $>5$ & 19 & 3.3 \\
\hline \multirow[t]{4}{*}{ Educational status } & No Formal education & 16 & 2.8 \\
\hline & Primary education & 99 & 17.1 \\
\hline & Secondary education & 304 & 52.4 \\
\hline & Diploma and above & 163 & 27.8 \\
\hline \multirow[t]{4}{*}{ Work experience in current occupation(years) } & $1-3$ & 295 & 50.9 \\
\hline & $4-8$ & 190 & 32.8 \\
\hline & $9-12$ & 63 & 10.3 \\
\hline & $>12$ & 32 & 5.5 \\
\hline Others $=7$ th day Adventist, Hawariyawi, & & & \\
\hline
\end{tabular}


Among the total study participants, $53.8 \%$ of respondents engaged in the woodwork industry. Regarding the noise exposure levels, nearly three-fourth $(72 \%)$ of respondents were exposed to noise levels greater than $95 \mathrm{dBA}$. The Majority (64.5\%) of respondents reported that they have raised their voice to be heard by their workmate within a one-meter distance in their workplace (Table 2). 
Table 2

Working condition and noise exposure level related factor with hearing impairment $(n=580)$

\begin{tabular}{|c|c|c|c|}
\hline Variable & Category & frequency & Percent \\
\hline \multirow[t]{2}{*}{ Current occupation } & Wood work & 312 & 53.8 \\
\hline & Metalwork & 268 & 46.2 \\
\hline \multirow[t]{6}{*}{ Previous occupation } & Construction & 20 & 3.4 \\
\hline & Mining & 1 & 0.2 \\
\hline & Garage & 43 & 7.4 \\
\hline & Military & 8 & 1.4 \\
\hline & Unemployed & 496 & 85.5 \\
\hline & Other & 12 & 2.1 \\
\hline \multirow[t]{3}{*}{ Work experience of Previous occupation } & $<2$ & 36 & 6.2 \\
\hline & $2-3$ & 12 & 2.1 \\
\hline & $>3$ & 10 & 1.7 \\
\hline \multirow[t]{4}{*}{ The average noise exposure level of current occupation } & $<90.0$ & 25 & 4.3 \\
\hline & $90-95.0$ & 137 & 23.6 \\
\hline & $95.1-99.0$ & 278 & 47.9 \\
\hline & $>99.1$ & 140 & 24.1 \\
\hline \multirow[t]{2}{*}{ Do you use power tools like a hammer, chainsaw } & Yes & 524 & 90.3 \\
\hline & No & 56 & 9.7 \\
\hline \multirow{2}{*}{$\begin{array}{l}\text { Do you raise your voice at the workplace to be heard by your } \\
\text { workmate in } 1 \text { meter distance }\end{array}$} & Yes & 374 & 64.5 \\
\hline & No & 206 & 35.5 \\
\hline \multirow[t]{2}{*}{ Does road noise is the source of noise in your workplace } & Yes & 333 & 57.4 \\
\hline & No & 247 & 42.6 \\
\hline \multirow[t]{3}{*}{ If yes, how do you rate noise source from traffic flow } & Small & 92 & 15.9 \\
\hline & Medium & 204 & 35.2 \\
\hline & High & 37 & 6.4 \\
\hline
\end{tabular}


Among the total study participants, only $6.9 \%$ of respondents utilize the hearing protective device, and out of those $2.2 \%$ used ear muffs. The majority $80.5 \%$ and $8.8 \%$ of respondents reported lack of provision and comfort issues as the main reason for non-utilization respectively. Above three-fourths, $(80.9 \%)$ of respondents listened to music and $30.5 \%$ of respondents drank alcohol (Table 3 ). 
Table 3

Behavioral characteristics of study participants in metal and woodwork industries, northwest Ethiopia, 2020.

\begin{tabular}{|c|c|c|c|}
\hline Variables & Category & Frequency & Percent \\
\hline \multirow[t]{2}{*}{ Do you use ear protective equipment } & Yes & 40 & 6.9 \\
\hline & No & 540 & 93.1 \\
\hline \multirow[t]{4}{*}{ Types of ear protective equipment } & Earmuff & 13 & 2.2 \\
\hline & Earplug & 7 & 1.2 \\
\hline & Head seat & 4 & 0.7 \\
\hline & Others/cotton & 16 & 2.8 \\
\hline \multirow{2}{*}{$\begin{array}{l}\text { If yes, how often do you wear hearing } \\
\text { protective equipment }\end{array}$} & Sometimes & 34 & 5.9 \\
\hline & Usually & 6 & 1 \\
\hline \multirow[t]{3}{*}{$\begin{array}{l}\text { If not use hearing protective equipment, the } \\
\text { reason that not use it }\end{array}$} & $\begin{array}{l}\text { It is not provided by the } \\
\text { employer }\end{array}$ & 467 & 80.5 \\
\hline & It is not comfortable & 51 & 8.8 \\
\hline & $\begin{array}{l}\text { I do not know to prevent } \\
\text { noise }\end{array}$ & 22 & 3.8 \\
\hline \multirow[t]{2}{*}{ Have you ever smoked a cigarette } & Yes & 22 & 3.8 \\
\hline & No & 559 & 96.2 \\
\hline \multirow[t]{2}{*}{ Do you currently smock cigarette } & Yes & 21 & 3.6 \\
\hline & No & 559 & 96.4 \\
\hline \multirow{2}{*}{$\begin{array}{l}\text { Have you consumed alcoholic beverages } \\
\text { regularly }\end{array}$} & Yes & 177 & 30.5 \\
\hline & No & 403 & 69.5 \\
\hline \multirow[t]{2}{*}{ Do you listen to music } & Yes & 469 & 80.9 \\
\hline & No & 111 & 19.1 \\
\hline \multirow[t]{3}{*}{ If yes. How loud you play this music } & Quite & 118 & 20.3 \\
\hline & Moderate & 296 & 51.1 \\
\hline & Loud & 55 & 9.5 \\
\hline \multirow{3}{*}{$\begin{array}{l}\text { How often do you use earphone to listen to } \\
\text { music or radio }\end{array}$} & Some times & 194 & 33.4 \\
\hline & Usually & 33 & 5.7 \\
\hline & Often & 15 & 2.6 \\
\hline
\end{tabular}




\begin{tabular}{|c|c|c|c|}
\hline Variables & Category & Frequency & Percent \\
\hline & Not use & 227 & 39.1 \\
\hline \multirow{2}{*}{$\begin{array}{l}\text { How many hours do you use earphone to listen } \\
\text { to music }\end{array}$} & $<2 h 228$ & & 39.3 \\
\hline & $>2 \mathrm{~h} 12$ & & 2.1 \\
\hline
\end{tabular}

The mean $( \pm S D)$ noise exposure level among wood and metalwork industries was $96.63 \pm 3.7 \mathrm{dBA}$ and the minimum and maximum noise exposure levels were $73.5 \mathrm{dBA}$ and $106.9 \mathrm{dBA}$ respectively. The maximum noise level in woodwork industries was $114 \mathrm{dBA}$ (circular saw) and in metal, a maximum of $108 \mathrm{dBA}$ (cutters and welding machine) was recorded. A significant difference in noise exposure level between metal and woodwork was observed $\left(x^{2}=15.1, d f=4, p=0.005\right)$ (Fig. 1).

\section{The prevalence of hearing impairments among the wood and metalwork industry}

According to this study, the overall prevalence of hearing impairments among wood and metalwork industry workers was $20.7 \%$ [95\% Cl: $17.4-24 \%$ ). From the total participants, $11.2 \%$ of the woodwork and $9.5 \%$ of metalwork industry workers reported hearing impairments. Moreover, $32.9 \%$ had communication difficulty and $26.4 \%$ had experienced tinnitus. besides, $16 \%$ and $8.4 \%$ of workers had trouble hearing conditions of the left and right ear without hearing aid respectively.

\section{Prevalence of NIHL in terms of industry}

The result of this study showed that the prevalence of hearing impairment was comparable among woodwork (20.8\%) and metalwork (20.5\%) industry workers, and no statistically significant difference has been observed $\left(x^{2}=0.008, d f=1\right.$, and $p$-value $\left.=0.5\right)($ Table 4$)$.

Table 4

Noise-induced hearing impairment and work categories

\begin{tabular}{|lllll|}
\hline \multirow{2}{*}{ Hearing impairment } & \multicolumn{2}{l}{ Work categories } & p-value \\
\cline { 2 - 4 } & Woodwork & Metalwork & Total & $>0.5$ \\
\cline { 1 - 4 } No & $247(79.2 \%)$ & $213(79.5 \%)$ & $460(79.3 \%)$ & \\
Yes & $65(20.8 \%)$ & $55(20.5 \%)$ & $120(20.7)$ & \\
\hline
\end{tabular}

\section{Factors Associated with hearing impairments}

As the multivariable logistic regression analysis indicated that listening to music with loud volume, and listening to music using earphones for more than two hours per day, were significantly associated with 
noise-induced hearing impairments. Workers who listening music with loud volume were 3.75 times more likely to develop hearing impairments than their counterparts [ AOR $=3.75(1.13,12.43)$ ]. Workers who listen to music using earphones for more than two hours per day were 5.33 times more likely to develop hearing impairments than their counterparts $[\mathrm{AOR}=5.33,95 \% \mathrm{Cl}: 1.29,21.9)]($ Table 6$)$. 
Table 6

Bivariate and Multivariable regression to identify factors associated with hearing impairment among wood and metalwork industry workers in Gondar town, 2020 $(n=580)$

\begin{tabular}{|c|c|c|c|c|c|}
\hline \multirow[t]{2}{*}{ Variables } & & \multicolumn{2}{|c|}{ Hearing impairments } & \multirow[t]{2}{*}{$\operatorname{coR}(95 \% \mathrm{Cl})$} & \multirow[t]{2}{*}{$\operatorname{AOR}(95 \% \mathrm{Cl})$} \\
\hline & & Yes & No & & \\
\hline \multirow[t]{4}{*}{ Educational level } & $\begin{array}{l}\text { No formal } \\
\text { education }\end{array}$ & $4(0.7)$ & $12(2.1)$ & $1.29(0.39,4.27)$ & $1.31(0.11,15.4)$ \\
\hline & $\begin{array}{l}\text { Primary } \\
\text { education }\end{array}$ & $26(4.8)$ & $71(12.2)$ & $1.53(0.86,2.73)$ & $1.84(0.62,5.43)$ \\
\hline & $\begin{array}{l}\text { Secondary } \\
\text { education }\end{array}$ & $55(9.5)$ & $249(42.9)$ & $0.86(0.53,1.38)$ & $0.74(0.33,1.68)$ \\
\hline & $\begin{array}{l}\text { Diploma and } \\
\text { above }\end{array}$ & $33(5.7)$ & $128(22.1)$ & 1 & \\
\hline \multirow[t]{4}{*}{ Monthly salary } & $<1500$ & $25(4.3)$ & $132(22.8)$ & $1.9(1.07,3.37)$ & $0.36(.012,1.04)$ \\
\hline & $1500-2000$ & $36(6.2)$ & $100(17.2)$ & $1.3(0.73,2.34)$ & $0.64(0.25,1.61)$ \\
\hline & $2001-3200$ & $29(5)$ & $117(20.2)$ & $1.43(0.79,2.57)$ & $0.57(0.21,1.56)$ \\
\hline & $>3200$ & $30(5.2)$ & 111(19.1) & 1 & \\
\hline \multirow{4}{*}{$\begin{array}{l}\text { Noise exposure } \\
\text { level }\end{array}$} & $<90.0$ & 4 & 21 & 1 & 1 \\
\hline & $90-95.0$ & 27 & 110 & $1.28(0.4,4.06)$ & $1.07(0.18,5.84)$ \\
\hline & $95.1-99.0$ & 64 & 214 & $1.57(0.52,4.74)$ & $1.05(0.19,5.6))$ \\
\hline & $>99.1$ & 25 & 115 & $1.14(0.36(3.60)$ & $0.92((0.153,5.5)$ \\
\hline \multirow{2}{*}{$\begin{array}{l}\text { Utilization ear } \\
\text { protective device }\end{array}$} & No & $117(20.2)$ & $423(72.9)$ & $3.41(1.03,11.3)$ & $2.37(0.50,11.14)$ \\
\hline & Yes & $3(0.5)$ & $37(6.4)$ & 1 & 1 \\
\hline \multirow{3}{*}{$\begin{array}{l}\text { How loud you play } \\
\text { this music }\end{array}$} & Quite & $22(3.8)$ & $96(16.6)$ & 1 & 1 \\
\hline & moderate & $63(10.9)$ & $233(40.2)$ & $1.4(0.78,2.49)$ & $2.31(0.93,5.74)$ \\
\hline & Loud & $17(2.9)$ & $38(6.6)$ & $2.31(1.08,4.96)$ & $3.75(1.13,12.43)$ \\
\hline \multirow{2}{*}{$\begin{array}{l}\text { Hours of use } \\
\text { earphone to listen } \\
\text { to music }\end{array}$} & $<-2$ hour & $6(50.0)$ & $6(50.0)$ & 1 & 1 \\
\hline & $>2$ hour & $45(19.7)$ & 183(80.3) & $4.1(1.25,13.2)$ & $5.33(1.29,21.9)$ \\
\hline \multirow{2}{*}{$\begin{array}{l}\text { Involvement in } \\
\text { dance concert }\end{array}$} & Yes & $15(27.8)$ & $39(72.2)$ & $1.54(0.82,2.9)$ & $1.85(0.74,4.61)$ \\
\hline & No(ref) & $105(20.0)$ & $421(80.0)$ & 1 & \\
\hline $\begin{array}{l}\text { Ear infection under } \\
\text { the age of } 18\end{array}$ & Yes & $18(15.0)$ & $28(6.1)$ & $2.7(1.45,5.11)$ & $2.23(0.67,7.60)$ \\
\hline
\end{tabular}




\begin{tabular}{|llllll|}
\hline & No(ref) & $102(85.0)$ & $432(93.9)$ & 1 & 1 \\
\hline $\begin{array}{l}\text { Ear infection above } \\
\text { the age of } 18\end{array}$ & Yes & $5(62.5)$ & $3(37.5)$ & $6.6(1.56,28.11)$ & $10.6(0.81,144.1)$ \\
\cline { 2 - 6 } & No(ref) & $115(20.1)$ & $457(79.9)$ & 1 & 1 \\
\hline \multirow{2}{*}{ Ear injury } & Yes & $2(0.4)$ & $4(3.3)$ & 1 & 1 \\
\cline { 2 - 6 } & No & $458(99.6)$ & $116(96.7)$ & $0.13(0.23,0.7)$ & $1.59(0.02,127.0)$ \\
\hline \multicolumn{2}{l}{ Model fitness test value $=0.655$} & & & & \\
\hline
\end{tabular}

\section{Discussion}

Based on this study, the prevalence of hearing impairment is comparable in metal and woodwork worker, but higher noise exposure level is recorded in woodwork industry and the majority of the employees exposed to the noise level above the permissible exposure limit value. Listening to music using earphones for more than two hours per day and playing music with loud volume was associated with hearing impairments.

In this study, the prevalence of self-reported hearing impairments among wood and metalwork workers was $20.7 \%$, which is in line with a study done in the United States among wood manufacturing industry workers $20.86 \%$ (20) and the study done in Ethiopia, among metalwork industry $22 \%(22)$. This similarity may be due to similar methods followed(cross-sectional and retrospective cross-section in the case of US )and characteristics of the worker. However, this study result is lower than a study done in Rwanda among the wood and metalwork industry (36\%)(23), and 31\% in Nepal among woodworkers (9). This difference might be attributed to differences in methods followed (audiogram test in Rwanda may be an increased prevalence), utilization of hearing protective device ( $0.5 \%$ in Rwanda, $6.6 \%$ in our study). Also, this difference could be justified by the duration of exposure or work experience. On the other hand, this finding is higher than the study conducted in a metalworking company in Brazil 15.9\% (24) and this difference may be because enforcement of occupational health and safety regulation is very weak in Ethiopia and the other may be due to high noise exposure level in Ethiopia.

In this study worker who listens to music using earphone for more than two hours per day were more likely to develop noise-induced hearing impairments when compared to their counterparts, and this finding is consistent with research done in Singapore which reported that one in six young person's is at risk of developing leisure $\mathrm{NIHL}$ from music delivered via earphones(25), and another study also indicated that listening music through headphone for 3 hours at their usual maximum level showed transient shifts of $10 \mathrm{~dB}$ and $30 \mathrm{~dB}$ and returned to normal within 24 hours and this can cause noise-induced hearing impairment if not reduced duration of exposure(26).

In this study, other factors that had a significant relation with noise-induced hearing impairment were listening to music with loud volume, and workers who were listening to music with loud volume were more likely to develop noise-induced hearing impairments than workers who didn't listen to music at loud 
volume. This finding is supported by research finding that reported exposure to loud leisure noise is correlated with hearing loss and tinnitus and the risk rises as noise exposure increases (27). And another study done among young individuals showed that listening to music too loud over a lengthy time on personal listening devices (PLDs) such as CDs, iPods, and other MP3 players has been shown as a potential contributor to NIHL (28).

Another finding of this study is the noise level of the wood and metalwork industry, which is not a significant factor for noise-induced hearing impairments and the finding is similar to a study done among the metalwork industry in Ethiopia, which was not significant for noise-induced hearing impairments (22). But in another study, the level of noise was one of the determining factors for $\mathrm{NIHI}(11,29,30)$ but the possible reason for noise level was not significant in this study is may be due to the short duration of exposure or work experience and the work nature is entertainments and not fully exposed for 8 hours for a noisy machine. And another reason may be the total noise intensity level may not be reached to workers as workers are mobile in the working environment.

According to this study, prevalence of self-reported hearing impairment was comparable among woodwork (20.8\%) and metalwork(20.5\%) industry workers and this finding is different from a study done among metal and woodwork industry workers and prevalence of hearing impairments was higher among metalwork (40\%) workers than woodwork (30\%) industry workers (23).

Regarding the noise exposure level of workers in their current occupation nearly three-fourth $(72 \%)$ of respondents exposed to noise levels greater than $95 \mathrm{dBA}$, which is above OSHA permissible exposure limit value for eight hours working time as it is considered hazardous (31). This finding shows that workers in the wood and metalwork industry work on hazardous noise condition for a long time (8 hours) as the country set occupational exposure limit to continuous noise at $90 \mathrm{dBA}, 92 \mathrm{dBA}, 95 \mathrm{dBA}, 95 \mathrm{dBA}, 97$ $\mathrm{dBA}, 100 \mathrm{dBA}, 102 \mathrm{dBA}, 105 \mathrm{dBA}, 110 \mathrm{dBA}, 115 \mathrm{dBA}$ to a period of $8,6,4,3,2,1$ and $1 / 2,1,1 / 2,1 / 4$, hours respectively (32).

\section{Limitation of the study}

The inability of measuring the personal noise exposure level using a noise dosimeter and not using an audiogram to assess the hearing impairments workers.

\section{Conclusion:}

The prevalence of hearing impairment is comparable in metal and woodwork industry worker, but higher noise exposure level is recorded in woodwork industry and the majority of the employees in both industries exposed to noise levels above the permissible exposure limit. Listening to music using earphones for more than two hours per day and playing music with loud volume was significantly associated with hearing impairments. Therefore, a hearing conservation program shall be implemented in this industry and especially with the use of personal music listening devices. 


\section{List Of Abbreviations}

AOR: Adjusted Odds Ratio; Cl: Confidence Interval; COR:Crude Odds Ratio; HI:Hearing Impairmen; IEC:International Electrotechnical Commission; NIHI: Noise Induced Hearing Impairment; OSHA: Occupational Safety and Health Administration ; SPSS: Statistical Package for Social Science;

\section{Declarations}

\section{Ethics approval and consent to participate}

For this research, the ethical issue was assured by an Institutional Review Committee of the University of Gondar, and participants were also informed and confidentiality assured by using an anonymous questionnaire and verbal consent was obtained from participants during data collection.

\section{Authors' contributions}

Eshetu Abera conceived the study and contributed to the data collection, data analysis, interpretations of the results, and manuscript write-up. Dr. Walelegn work comment and edit the interpretation of statistical output and approved the submitted version of the manuscript. Mr. Sintayehu daba contributed in data analysis ,comment and edit the interpretation of statistical output,manuscript write up and approved the submitted version of the manuscript.

\section{Consent for publication}

Not applicable.

\section{Availability of data and materials}

All data generated for this study are included in this article. The data are also available from the corresponding author upon reasonable request.

\section{Competing interests}

Authors declare that they have no competing interests.

\section{Funding}

There was no source of funding for this study.

\section{Acknowledgments}

First, I would like to thank my research advisors, Dr.Walelegn Worku (Ph.D., Assoc. pro) and Mr. Sintayehu Daba (MPH, Assis. pro) for their friendly support and involvement throughout the proposal development to research thesis work. 
I would like to thank the University of Gondar and the Environmental and occupational safety and health department for every effort they exerted.

I would like also to thank Gondar town industrial development office, owners, and study participants for their positive involvement during the data collection period.

Last but not least, I would like to thank data collectors, supervisors, and my families and friends who have contributed directly or indirectly to the successful completion of the research.

\section{References}

1. Noweir MH, Bafail AO, Jomoah IM. Noise Pollution in Metalwork and Woodwork Industries in the Kingdom of Saudi Arabia. International Journal of Occupational Safety Ergonomics. 2014;20(4):661-70.

2. Hong 0 , Kerr MJ, Poling GL, Dhar S. Understanding and preventing noise-induced hearing loss. Dis Mon. 2013;59(4):110-8.

3. Institute EZSMME, Robert S. Hong MD P. Noise induced hearing loss:An occupational medicine perspective.

4. EDITORIAL. Noise-induced hearing loss. Indian Journal of Otology | | October 2014; Vol 20 (| Issue 4 I).

5. Marisol Concha-Barrientos DC-LKS. Assessing the burden of disease from work-related hearing impairment at national and local levels 2004.

6. Whittaker JD, Robinson T, Acharya A, Singh D, Smith M. Noise-induced hearing loss in the small-scale metal industry in Nepal. The Journal of Laryngology Otology. 2014;128(10):871-80.

7. SangWoo Tak S, MPH1* Rickie R, Davis, PhD2 and Geoffrey M. Calvert, MD, MPH1. Exposure to Hazardous Workplace Noise and Use of Hearing Protection Devices Among US Workers-NHANES, AMERICAN JOURNAL OF INDUSTRIAL MEDICINE 21 January 2009.

8. Reddy R 1, DW S. Ameratunga2 and P. Thorne1 Development of the hearing protection assessment (HPA-2) questionnaires. 2014(64):198-205.

9. Tim Robinson1 JW. Aanand Acharya2, Devesh Singh3, Michael Smith4. Prevalence of noise-induced hearing loss among woodworkers in Nepal: a pilot study. 2015.

10. Ghnimat NAaT. Awareness of Noise-Induced Hearing Loss and Use of Hearing Protection among Young Adults in Jordan. 2019.

11. Ferrite S, Santana V. Joint effects of smoking, noise exposure, and age on hearing loss. Occup Med. 2005;55(1):48-53.

12. Ilias Bougoudis LL. Vasiliki Dimou Democritus. Computational Intelligence modeling and assessment of industrial noise: The case of wood manufacturing International journal of engineering intelligent systems for electrical engineering and communications $\cdot 2014$.

13. Penafiel E. Developing a Questionnaire to Assess Noise Exposure in Children and Teens. 2007. 
14. Colleen G. Le Prell G, Donald Henderson FL, Buffalo NY, Richard R, Fay, Falmouth MA, Arthur N, Popper. College Park, MD. Noise-Induced Hearing Loss. 2012.

15. Israel P. Nyarubeli 1, 3,*, Tungu AM 4, Bente E. Moen 1,3 and Magne Bråtveit 3 Prevalence of NoiseInduced Hearing Loss Among Tanzanian Iron and Steel Workers: A Cross-Sectional Study. International journal of environmental research and public health 13 April 2019.

16. Hearing loss. due to recreational exposure to loud sounds. 2015.

17. Bortkiewicz3 MP-ŁADNCA. DO HEARING THRESHOLD LEVELS IN. WORKERS OF THE FURNITURE INDUSTRY REFLECT THEIR EXPOSURE TO NOISE. 2016.

18. M. Rosso1 RAaNC. Development and validation of a screening questionnaire for noise-induced hearing loss. 2011.

19. Professor PW, Alberti. MH-SA. Occupational exposure to noise evaluation, prevention, and control. 1998.

20. Masterson EA, Tak S, Themann CL, Wall DK, Groenewold MR, Deddens JA, et al. Prevalence of hearing loss in the United States by industry. Am J Ind Med. 2013;56(6):670-81.

21. Muca A, Standafer E, Apawu AK, Ahmad F, Ghoddoussi F, Hali M, et al. Tinnitus and temporary hearing loss result in differential noise-induced spatial reorganization of brain activity. Brain Struct Funct. 2018;223(5):2343-60.

22. ASHENAFI HAILU DAAM MPH, MA PhD), DR AYELE BELACHEW (MD, MPH, Ph.D. FELLOW) ASSESSMENT OF NOISE INDUCED HEARING LOSS AND ASSOCIATED FACTORS AMONG WORKERS IN AKAKI BASIC METAL INDUSTRY, ADDIS ABABA, ETHIOPIA JUNE, 2015 (JUNE, 2015).

23. Bukuru John1, Byiringiro Fidele2. Mukara B. Kaitesi3, Twagirumukiza Eugene1, Sayinzoga Christopher1, Ngoga Eugene1 Kagimbana Jean Chrysostome1. Prevalence of occupational noiseinduced hearing loss among wood and metal workers of Gakiriro. Kigali city. 2019;1(1):20-5.

24. Alves MRGPMCLMTB-TMJM. Prevalence of noise-induced hearing loss in the metallurgical company. Received on 13/10/2003. Reviewed on 21/6/2004. Approved on 14/7/2004.

25. Gary Jek Chong Lee1. BEng MCIAud. Ming Yann Lim2*, MBBS, FAMS, Angeline Yi Wei Kuan1, Joshua Han Wei Teo1, Hui Guang Tan1, Wong Kein Low2, FRCS, Ph.D. The music listening preferences and habits of youths in Singapore and its relation to leisure noise-induced hearing loss. 2014.

26. Tung $\mathrm{C}-\mathrm{Y}$, Chao K-P. Effect of recreational noise exposure on hearing impairment among teenage students. Res Dev Disabil. 2013;34(1):126-32.

27. Holgers KMPB. Noise exposure and subjective hearing symptoms among schoolchildren in Sweden. Noise Health. 2005;7(11:27-37.

28. Sandra Levey City University of New York LC. the Bronx NY, Brian J Fligor Children's Hospital Boston and Harvard Medical School, MA Caterina Gnocchi Loise Kagimbi City University of New York, Lehman College. The Effects of Noise-Induced Hearing Loss on Children and Young Adult. 2012.

29. Ayele Belachew1 YB. Noise-induced hearing loss among textile workers. 1994. 
30. Foluwasayo EOea. Occupational noise exposure and sensorineural hearing loss among workers of a steel rolling mill in Nigeria. Eur Aarch otorhinolaryngeal. 2006;266(618-621):618.

31. Safety, Nifoha. 1998.

32. federal Democratic Republic. of Ethiopia Ministry of labor and social affairs osahd. May 2008, Addis Abeba.

\section{Figures}

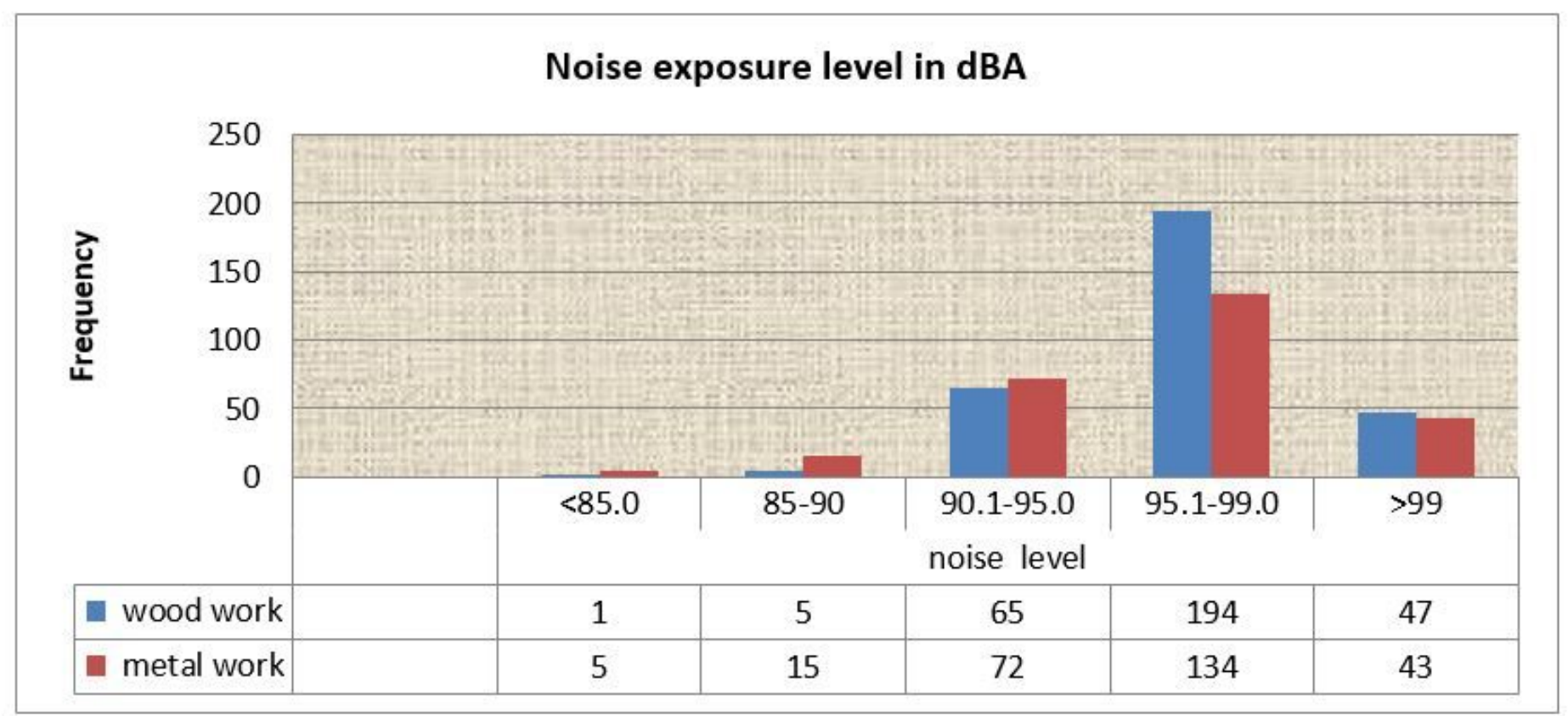

Figure 1

Average noise level between wood and metalwork industry in Gondar town, 2020. 